Gi respons på artikler gjennom artiklenes kommentarfelt på tidsskriftet.no.

Innleggene publiseres fortløpende på Tidsskriftets nettside og et utvalg

av innleggene publiseres også i papirutgaven i spalten «Brev til redaktøren».

Redaksjonen forbeholder seg retten til å foreta redaksjonelle endringer.

Forfattere av vitenskapelige artikler har tilsvarsrett, jf. Vancouver-gruppens regler.

\section{Re: Legers private henvisningspraksis}

Hyttens svar til min kritiske kommentar til hans artikkel om legers private henvisningspraksis (1) er for så vidt klargjørende, men etter min oppfatning egentlig i negativ forstand. Som i sitt opprinnelige innlegg, viser han til Etiske regler kap. I $§ 12$, og fremsetter at det finnes medisinsk begrunnede situasjoner, og endog elektive situasjoner, hvor direkte henvendelse til sykehus eller annen spesialisttjeneste kan være ressurssparende. Dette vil selvfølgelig ingen benekte, men det er ikke dette saken gjelder.

Mitt poeng var og er at en norsk lege med sin autorisasjon i orden fortsatt er i sin fulle rett til å utøve vanlig legearbeid, herunder også henvisninger etter vanlig faglig og yrkesetisk standard, uten à måtte begrunne dette med at det foreligger en slags unntakssituasjon med spesielle medisinske eller ressursmessige forhold. Hyttens svar forsterker inntrykket av at Rådet for legeetikk egentlig mener at det nærmest er uetisk å behandle og henvise pasienter utenom fastlegesystemet. Jeg gjentar derfor at det ikke tilligger Etikkrådet å uttale seg om hvilke leger som ikke kan eller bør henvise pasienter. Dette er ikke regulert i etikkreglene, og Rådet bør holde seg innenfor sitt mandat og sin kompetanse.

\section{Torbjørn Pihl}

fam.pihl@frisurf.no

Torbjørn Pihl (f. 1940) er pensjonert sykehuslege.

Ingen oppgitte interessekonflikter.

\section{Litteratur}

1. Hytten K. Legers private henvisningspraksis. Tidsskr Nor Legeforen 2014; 134 435.

\section{Re: Kan nye blodfortynnende legemidler være mer risikable enn tidligere antatt?}

I Tidsskriftet nr. 8/2014 har Harg og medarbeidere en viktig kommentar til risikoen ved bruk av nye blodfortynnende legemidler (1). Hensikten er tydelig å belyse spørsmålet slik at ikke bare leger kan forstå det. Jeg vil kritisere forfatternes bruk av begrepet «bivirkning». Får man ulcussykdom av NSAIDs, er dette en ekte bivirkning. Hvis man overdoserer Marevan og får blødning på grunn av for sterk koagulasjonshemning, er dette en virkning eller effekt av doseringen. Kommer det en arteriell blødning under behandlingen, vil Marevan kanskje få skylden, hvilket er feil. Fordelen med Marevan framfor de nyere antikoagulantia er at INR-måling er en trygg monitorering av behandlingen.

\section{Carl Ditlef Jacobsen}

$c d-j @ o n l i n e . n o$

Carl Ditlef Jacobsen (f. 1930) er pensjonert lege og tidligere medlem av bivirkningsnemnda.

Ingen oppgitte interessekonflikter

\section{Litteratur}

1. Harg P, Samdal H, Simensen A et al. Kan nye blodfortynnende legemidler være mer risikable enn tidligere antatt? Tidsskr Nor Legeforen 2014; 134: 817.

\section{S. Madsen og medarbeidere svarer:}

Vi er ikke enige i Jacobsens synspunkt på hva «bivirkninger» innebærer. En av de viktige endringene på bivirkningsområdet de siste årene er innføringen av det vi kaller det «utvidete bivirkningsbegrep». Dette omfatter alle former for uheldige hendelser ved legemiddelbruk, blant annet tradisjonelle bivirkninger, lege- og pasientfeil, manglende virkning og avhengighet. Når det gjelder de nye blodfortynnende midlene er det nettopp viktig å være oppmerksom på alle former for uheldig bruk. Vi er opptatt av hvordan legemidlene fungerer i praktisk bruk.

\section{Steinar Madsen}

steinar.madsen@legemiddelverket.no

Pernille Harg

Hilde Samdal

Ane Simensen

Steinar Madsen (f. 1956) er medisinsk fagdirektør ved Statens legemiddelverk og deltids avtalespesialist i indremedisin og hjertesykdommer. Ingen oppgitte interessekonflikter.

Pernille Harg (f. 1975) er cand.pharm. og seniorrådgiver ved Seksjon for legemiddelovervåking, Statens legemiddelverk.

Ingen oppgitte interessekonflikter.

Hilde Samdal (f. 1975) er master i farmasi og seniorrådgiver ved Seksjon for legemiddelovervåking, Statens legemiddelverk.

Ingen oppgitte interessekonflikter.

Ane S. Simensen (f. 1984) er master i molekylærmedisin og forsker ved Seksjon for legemiddelovervåking, Statens legemiddelverk.

Ingen oppgitte interessekonflikter.

\section{Re: Hva bør non-inferiority-studier kalles på norsk?}

Ideen Gjersvik og medarbeidere presenterer (1) er ikke helt ny, men jeg er i tvil om den er god. Jeg har gjennom mange år i studentforelesninger og foredrag muntlig forklart begrepet non-inferiority med «ikke-mindreverdighet» eller «ikke-underlegenhet», men har betraktet oversettelsen mest som en fleip. De fleste synes å være enige $i$ at ingen av disse begrepene klinger særlig godt.

Valg av ord kan vi godt være uenige om. Et større problem er Figur $1 \mathrm{i}$ artikkelen (1). Den mener jeg kun er egnet til å forvirre leseren.

I kliniske studier viser man normalt non-inferiority (ikke-underlegenhet) for en ny behandling (i figuren kalt testbehandling) ved å dokumentere at den nedre grensen i et (tosidig) $95 \%$ konfidensintervall (eller et ensidig 97.5\% konfidensintervall) for forskjellen i effekt mellom testbehandling og kontrollbehandling er større enn $-\Delta$ (en grense som skal defineres på forhånd og som utgjør en effektforskjell som er så liten at den anses å være uten klinisk betydning) (2). Det er uklart for meg hva forfatterne vil med å definere to forskjellige grenser $(\mathrm{d} \operatorname{og} \Delta)$, og hva som er forskjellen mellom ekvivalensspenn og ekvivalensmargin bortsett fra at den sistnevnte er ensidig. For øvrig skulle den vel heller vært kalt underlegenhetsmargin (eller underlegenhetsgrense)?

At forfatterne velger å speilvende problemet er selvsagt helt greit, men her har det resultert $i$ at de forholder seg til den gale 